\author{
Abstracta Iranica \\ Abstracta Iranica Revue bibliographique pour le domaine irano-aryen \\ Volume 37-38-39 | 2018 \\ Comptes rendus des publications de 2014-2016
}

\title{
Rika Gyselen, « Some Thoughts on Sasanian mgwh- Seals »
}

Julien Cuny

\section{(2) OpenEdition \\ 1 Journals}

\section{Édition électronique}

URL : http://journals.openedition.org/abstractairanica/46307

DOI : 10.4000/abstractairanica.46307

ISBN : 1961-960X

ISSN : 1961-960X

Éditeur :

CNRS (UMR 7528 Mondes iraniens et indiens), Éditions de l'IFRI

Référence électronique

Julien Cuny, «Rika Gyselen, « Some Thoughts on Sasanian mgwh-Seals » », Abstracta Iranica [En ligne], Volume 37-38-39 | 2018, document 39, mis en ligne le 30 décembre 2018, consulté le 28 septembre 2020. URL : http://journals.openedition.org/abstractairanica/46307 ; DOI : https://doi.org/ 10.4000/abstractairanica.46307

Ce document a été généré automatiquement le 28 septembre 2020

Tous droits réservés 


\title{
Rika Gyselen, « Some Thoughts on Sasanian mgwh-Seals »
}

\author{
Julien Cuny
}

\section{RÉFÉRENCE}

Rika Gyselen, « Some Thoughts on Sasanian mgwh-Seals » in S. Farridnejad, R. Gyselen, A. Joisten-Pruschke (eds.). Faszination Iran: Beiträge zur Religion, Geschichte und Kunst des Alten Iran. Gedenkschrift für Klaus Schippman. Wiesbaden: Harrassowitz Verlag, 2015, p. 87-99 (Göttinger Orientforschungen, Neue Folge 13)

1 L'A. propose un état des connaissances sur l'administration du mgwh, qui n'est connue que par la sigillographie. Le mot, de lecture incertaine, rendu ici par la seule transcription, est désormais lu mowūh par l'A. (cf. c.r. Blet-Lemarquand et Gyselen in Rika Gyselen (éds.). Argenterie, documents et monnaies de tradition sassanide). Sont discutés : la nature de cette administration, tenue par le clergé mazdéen, son rôle, sa période d'existence et sa répartition géographique au sein de l'empire sassanide, étayée par deux sceaux inédits dont un provient de la région de Merv.

\section{AUTEURS}

\section{JULIEN CUNY}

Conservateur au Musée du Louvre, Paris 